\title{
Vaccines and Antibodies for Therapeutic Use in Cancers
}

\author{
G. P. Talwar1*, Jagdish C. Gupta1, M. Diwan'1, J. Frick², S. K. Sharma ${ }^{3}$, S. N. Wadhwa4, \\ R. Gupta5 ${ }^{5}$ S. K. Gupta5, Shilpi Purswani' ${ }^{1}$, Hemant K. Vyas ${ }^{1}$ \\ ${ }^{1}$ Talwar Research Foundation, New Delhi, India \\ ${ }^{2}$ Urologische Zentrum Salzburg, Salzburg, Austria \\ ${ }^{3}$ Post Graduate Institute of Medical Education and Research (PGIMER), Chandigarh, India \\ ${ }^{4}$ Sir Ganga Ram Hospital, New Delhi, India \\ ${ }^{5}$ National Institute of Immunology, New Delhi, India \\ Email: "gptalwar@gmail.com
}

Received 29 April 2016; accepted 11 June 2016; published 14 June 2016

Copyright (C) 2016 by authors and Scientific Research Publishing Inc. This work is licensed under the Creative Commons Attribution International License (CC BY). http://creativecommons.org/licenses/by/4.0/

c) (i) Open Access

\section{Abstract}

This review describes briefly the beneficial use of two vaccines developed by us for treatment of cancers. The vaccine against Luteinizing Hormone Releasing Hormone (LHRH) is effective in carcinoma of prostate as well as in breast cancers dependent on androgens and estrogens respectively. LHRH being identical in both males and females, the same vaccine is usable in both Prostate and Breast steroid hormones-dependent-cancers. Monoclonal antibodies are finding therapeutic utility in several cancers, and many have received Drugs Regulatory approval. The monoclonals developed by us against hCG and against epitopes present on androgen-independent castration resistant prostate cancers are briefly recapitulated. Anti-hCG antibodies kill several cancers expressing hCG. An example is given of A549 lung carcinoma. MoAb730 and MoAb7B2G10 kill DU-145 and PC-3 androgen-independent castration resistant prostate cancer cells. Some cancers such as MOLT-4, a T-lymphoblastic leukemia, though expressing hCG are not killed by PiPP, the high affinity anti-hCG antibody. Linking the antibody to curcumin however works like a "Magic Bullet". All MOLT-4 cells are killed by this conjugate, the antibody homes selectively to cancer cells expressing hCG to deliver curcumin which exercises the killing effect. A recombinant vaccine, hCG $\beta$-LTB (human chorionic gonadotropin subunit $\beta$ linked to B subunit of heat-labile enterotoxin of $E$. coli) has been made, which induces high titre bioeffective antibodies not only in BalbC, but also in other genetic strains of mice. The vaccine employs autoclaved Mycobacterium indicus pranii (MiP) as adjuvant. MiP invigorates both humoral and cell mediated immune responses against Human chorionic gonadotropin (hCG). Besides being a potent adjuvant, MiP used alone heals anogenital warts in humans and has the property of preventing and curing SP2/0 Myelomas in mice.

"Corresponding author.

How to cite this paper: Talwar, G.P., Gupta, J.C., Diwan, M., Frick, J., Sharma, S.K., Wadhwa, S.N., Gupta, R., Gupta, S.K., Purswani, S. and Vyas, H.K. (2016) Vaccines and Antibodies for Therapeutic Use in Cancers. Journal of Cancer Therapy, 7, 370-377. http://dx.doi.org/10.4236/jct.2016.76040 


\section{Keywords}

\section{Human Chorionic Gonadotropin (hCG), LHRH, Prostate Cancer, Breast Cancer, Antibody-Curcumin Magic Bullets}

\section{Introduction}

Carcinoma of Prostate and Breast Cancers are 2 major cancers from which men and women suffer in India and all over the world. Prostate carcinoma cell proliferation is dependent up to a late stage on testosterone and antiandrogens are employed as drugs to control the cancer. These are replaceable by a vaccine against LHRH. LHRH is a decapeptide hormone which stimulates Follicle stimulating hormone (FSH) and Luteinizing hormone (LH) production by the pituitary. These in turn act on the male/female gonads to not only generate sperm and egg, but also the respective sex hormones: estrogens in the females and testosterone in males. LHRH is identical in men and women and is a largely conserved decapeptide in all mammals. Thus a vaccine against LHRH is usable in both males and females to block eventually the production of testosterone or estrogens, as also in dogs and stray animals to block their fertility.

\section{Vaccine against LHRH}

We made a synthetic vaccine against LHRH, replacing glycine at position 6 by lysine, to which via a linker, a carrier tetanus toxoid (TT) or diphtheria toxoid (DT) was conjugated [1] (Figure 1).

This vaccine generated bioeffective antibodies against LHRH, causing a virtual orchiectomy with testosterone declining to near zero levels [2]. After toxicology and safety studies and permission of Ethical and Drugs Regulatory Authorities, it was employed in 28 patients of Carcinoma of Prostate in 2 Centers of India, the All India Institute of Medical Sciences (AIIMS), New Delhi and Post Graduate Institute of Medical Education and Research (PGIMER), Chandigarh, and one in Austria, the Urologische Zentrum Salzburg. Figure 2 shows its action in a patient in Austria. After 3 primary immunization of the vaccine given at monthly interval, anti-LHRH antibodies were generated, which brought down the testosterone of the patient, as also PSA (Prostate Specific Antigen). On decline of antibodies, these increased again, but were again brought down by a booster injection of the vaccine.

Figure 3 shows the effect of this vaccine in a patient at PGIMER, Chandigarh. On immunization, the prostatic mass shrunk perceptibly.

Table 1 gives the summary of observations in 12 patients investigated by Prof. SN Wadhwa at AIIMS, New Delhi. Six were given a dose of $200 \mu \mathrm{g}$ of the vaccine and 6 immunized with $400 \mu \mathrm{g}$ of the vaccine. $400 \mu \mathrm{g}$ vaccine was more effective than $200 \mu \mathrm{g}$.

These studies indicate the utility of immunization against LHRH, which demand only periodic intervention and are cost effective as compared to the use of synthetic anti-androgens.

\section{Androgen Independent Stage of Carcinoma of Prostate}

A stage arrives, when the cancer from which they suffer is no longer responsive to anti-androgens. This is the stage at which deaths occur of subjects suffering from this cancer. We developed monoclonal antibodies against

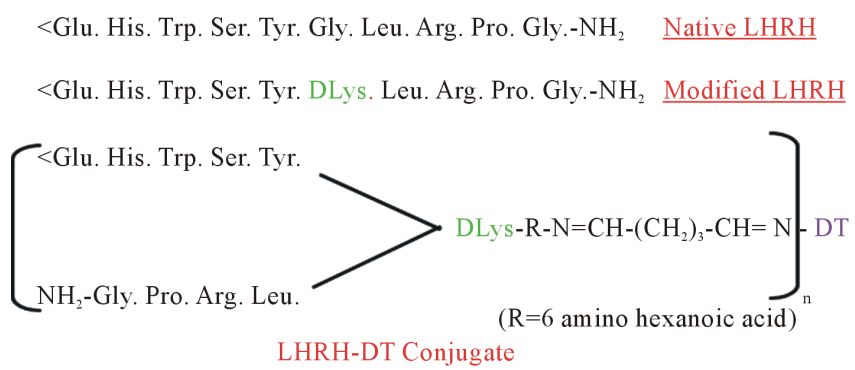

Figure 1. Amino acid sequence of LHRH-DT vaccine. 
R.J. 81 Years. Carcinoma of Prostate

(D2)
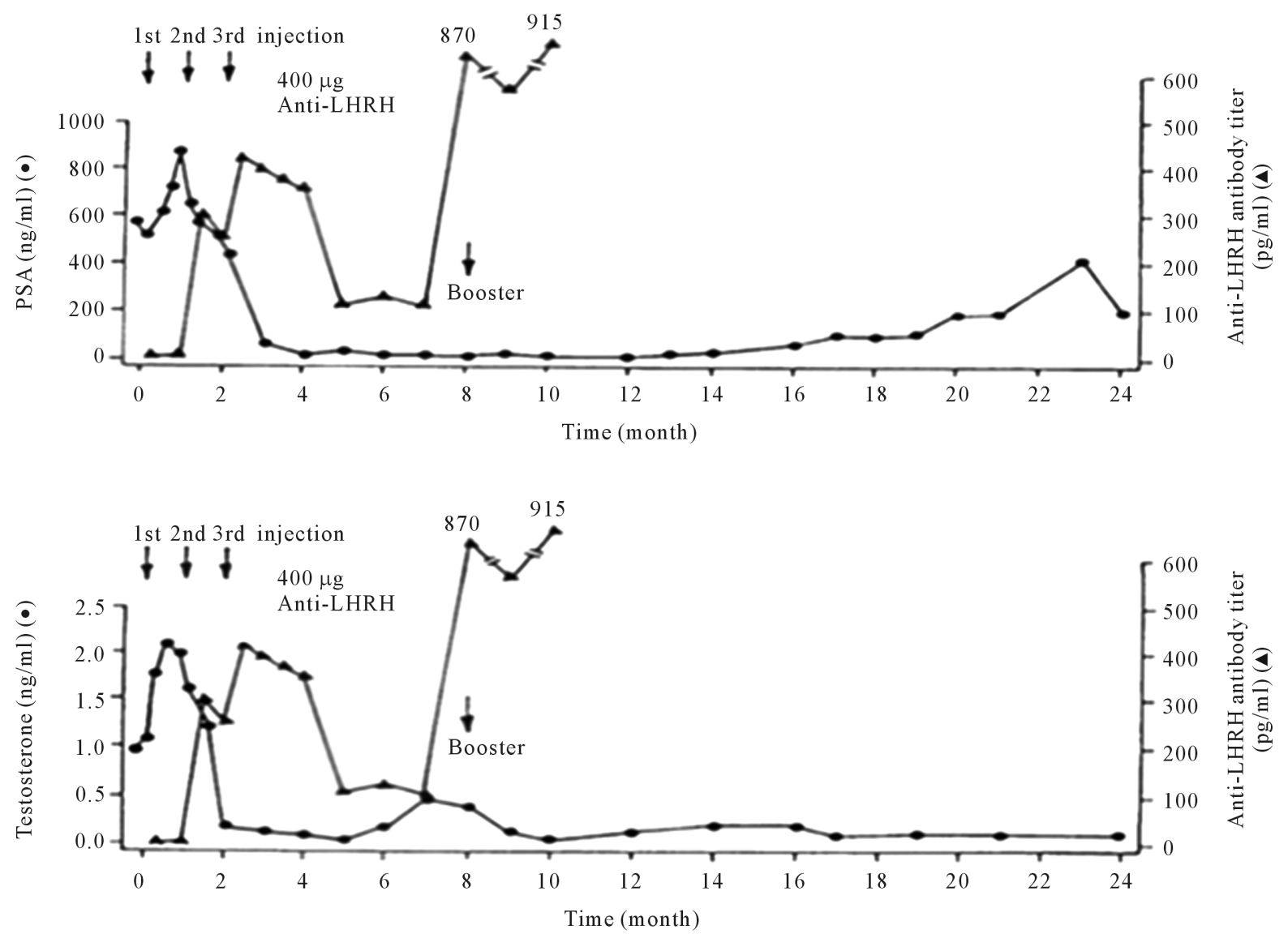

Figure 2. Effect of anti-LHRH vaccine on a patient with advanced carcinoma of prostate in Austria. With the generation of antibodies, testosterone and prostatic specific antigen (PSA) levels fall and stay low for several months [2].

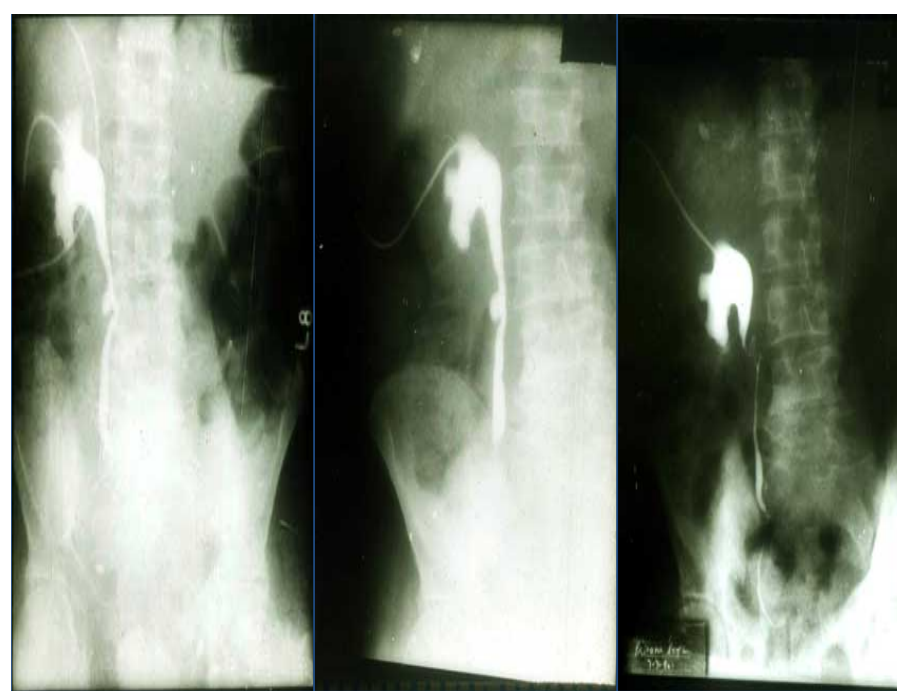

Figure 3. Nephrostograms showing the noticeable reduction of prostatic tissue mass at various stages of immunization with anti-LHRH vaccine [2]. 
DU-145 and PC-3 cells apparently derived from patients dying of androgens-resistant cancers [3]. The monoclonals developed kill both DU-145 and PC-3 cells in dose dependent manner in the presence of complement (Figure 4).

The cytotoxic action of MoAb 730 plateaued at killing only $70 \%$ - 80\% of DU-145 cells, pointing to the existence of heterogeneity of cell types in cancers, thereby demanding the requirement of additional antibodies targeting alternate epitopes. Three more monoclonal antibodies were developed [4]. Employing a combination of these enabled the killing of nearly 98\% of DU 145 cells (Figure 5).

Thus the combination of antibodies did succeed in killing almost all cancer cells. The lysis of cancer cells by these antibodies in vitro demanded complement activation following the binding of the antibodies to the epitopes on membranes of DU-145 and PC-3 cells.

\section{Expression of hCG by Various Advanced Stage Cancers}

Human Chorionic Gonadotropin (hCG) is normally made by the early embryo soon after fertilization of the egg [5]. It plays an important role in implantation of the embryo and sustenance of pregnancy. Neither non pregnant females, nor healthy males make this hormone. Since late, however several reports have appeared on ectopic or unexpected expression of hCG or its subunits by a variety of cancers: lung cancer [6], bladder carcinoma [7] [8], pancreatic carcinoma [9] [10], breast cancer [11], cervical carcinoma [12] [13], oral cancers [14] [15], head and neck cancers [16], prostate cancer [17], renal carcinoma [18], colon adenocarcinoma [19], gastric carcinoma [20] [21], vulva/vaginal cancers [22] [23]. Invariably the expression of hCG/subunits takes place at an advanced stage of cancer. The prognosis of such cancers is poor and survival adverse of the patients carrying the $\beta$-hCG expressing cancers [24].

Table 1. Observations in clinical trials conducted at AIIMS in patients of carcinoma of prostate after immunization with either $200 \mu \mathrm{g}$ or $400 \mu \mathrm{g}$ of anti-LHRH vaccine. Vaccine was administered as 3 primary injections at monthly interval followed by a booster at $8^{\text {th }}$ month [2].

\begin{tabular}{ccc}
\hline \multirow{2}{*}{ Effect of Immunization } & \multicolumn{2}{c}{ Dose Level } \\
\cline { 2 - 3 } & $\begin{array}{l}200 \mu \mathrm{g} \\
(\mathrm{n}=6)\end{array}$ & $\begin{array}{c}400 \mu \mathrm{g} \\
(\mathrm{n}=6)\end{array}$ \\
\hline Clinically Stable/Improvement in Symptoms & 4 & 5 \\
Reduction in Prostatic Size/Hardness & 1 & 3 \\
Reduction in Acid Phosphatases & 1 & 4 \\
\hline
\end{tabular}

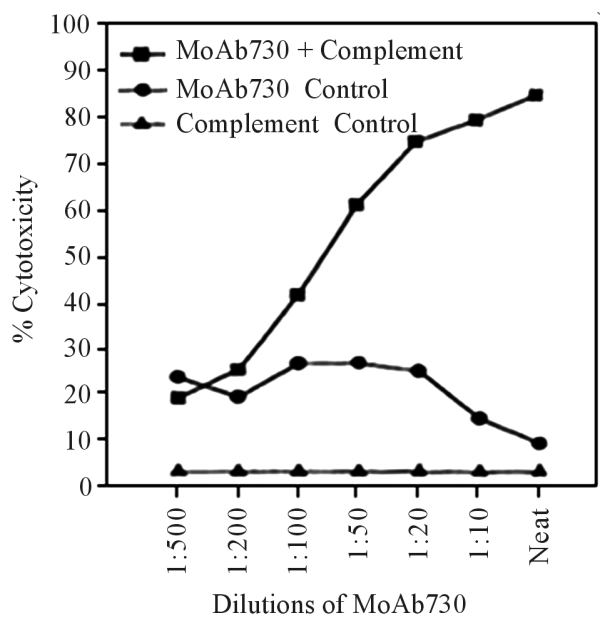

Figure 4. Cytotoxicity of MoAb730 on androgen-independent castration-resistant prostate cancer cells, DU145 [3]. 
We developed a high affinity monoclonal antibody (PiPP) with high specificity for hCG [25]. This antibody has the capability of killing several hCG expressing cancers in culture. Figure 6 shows its concentration-dependent-cytotoxic action against a lung cancer cell line A549 [26]. It can also be used for imaging of metastatic cancer cells. Radio-iodinated antibodies home to cells to locate such cancers [27].

We have developed also a highly immunogenic recombinant vaccine against hCG in which the $\beta$-subunit of hCG is linked to B subunit of heat labile enterotoxin of E. coli [28]. Figure 7 shows the vaccine design. The vaccine induces high titre bio-effective antibodies against hCG in BalbC mice [28] as well as in various other genetic strains of mice [29]. The vaccine should find a valuable application in treatment of cancer patients suffering from advanced stage cancers expressing ectopically hCG.

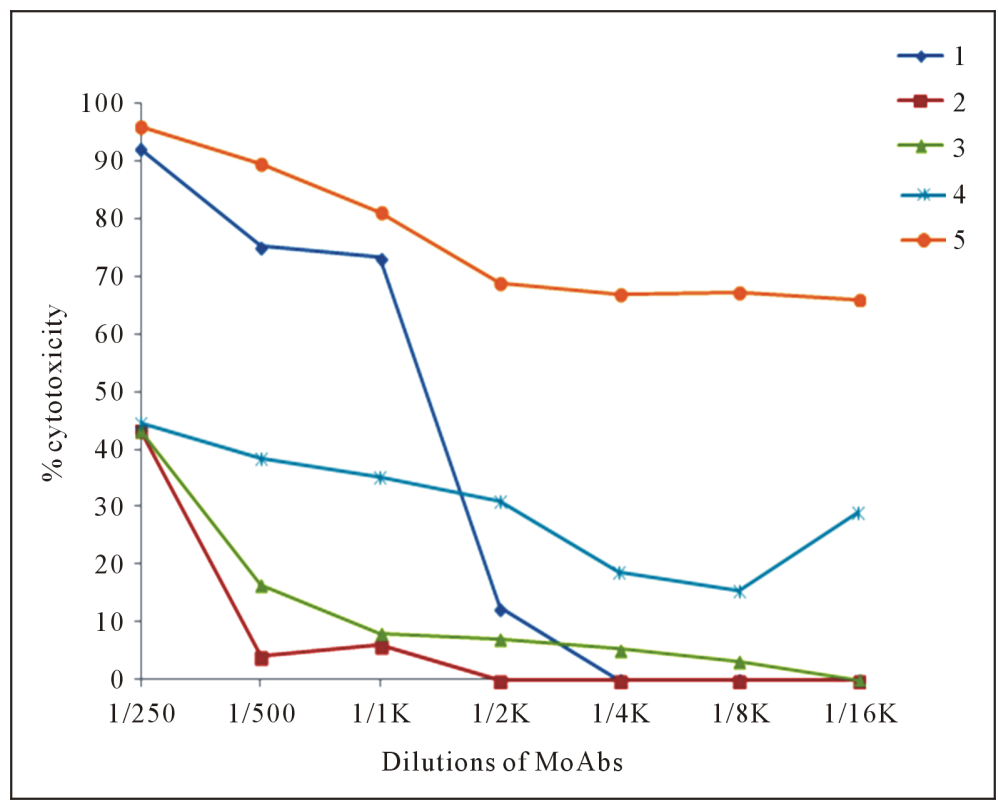

Figure 5. Synergistic cytotoxic action of MoAbs on androgen-independent castration-resistant prostate cancer cells, DU145. Cytotoxicity was determined by colorimetric, 3-(4,5-dimethylthiazol-2-yl)-2,5-diphenyltetrazolium bromide (MTT) assay [1 = 7B2G10, 2 = 730, $3=$ 3C8D4, $4=730$ + 3C8D4, $\mathbf{5}=7 \mathrm{~B} 2 \mathrm{G} 10+$ 3C8D4] [4].

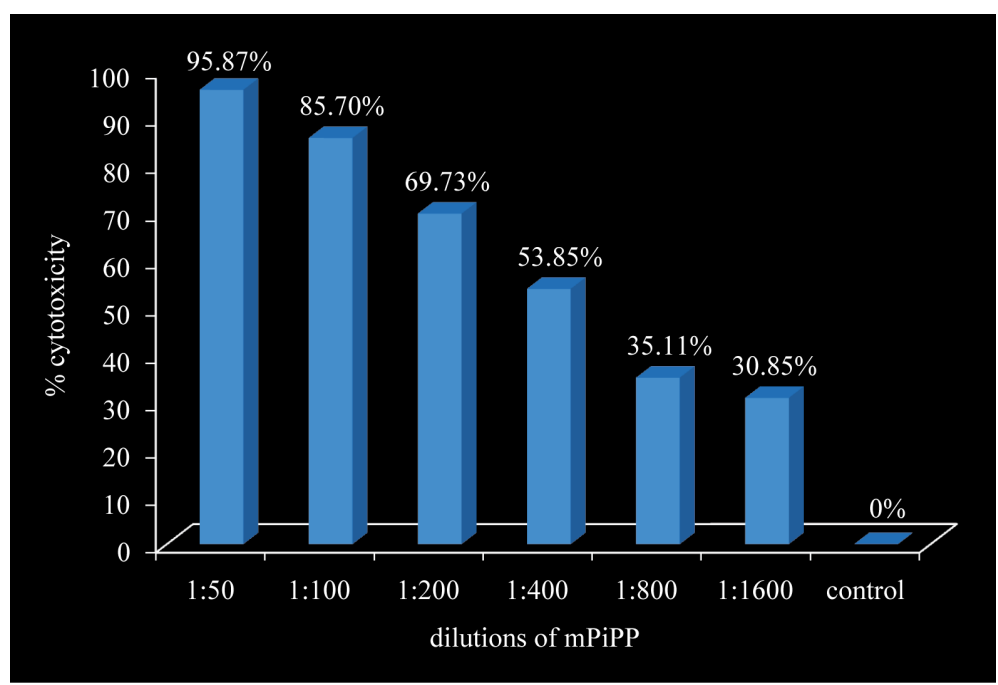

Figure 6. Dose dependent cytotoxicity exercised by a monoclonal anti-hCGantibody cPiPP on lung cancer cells (A549). 


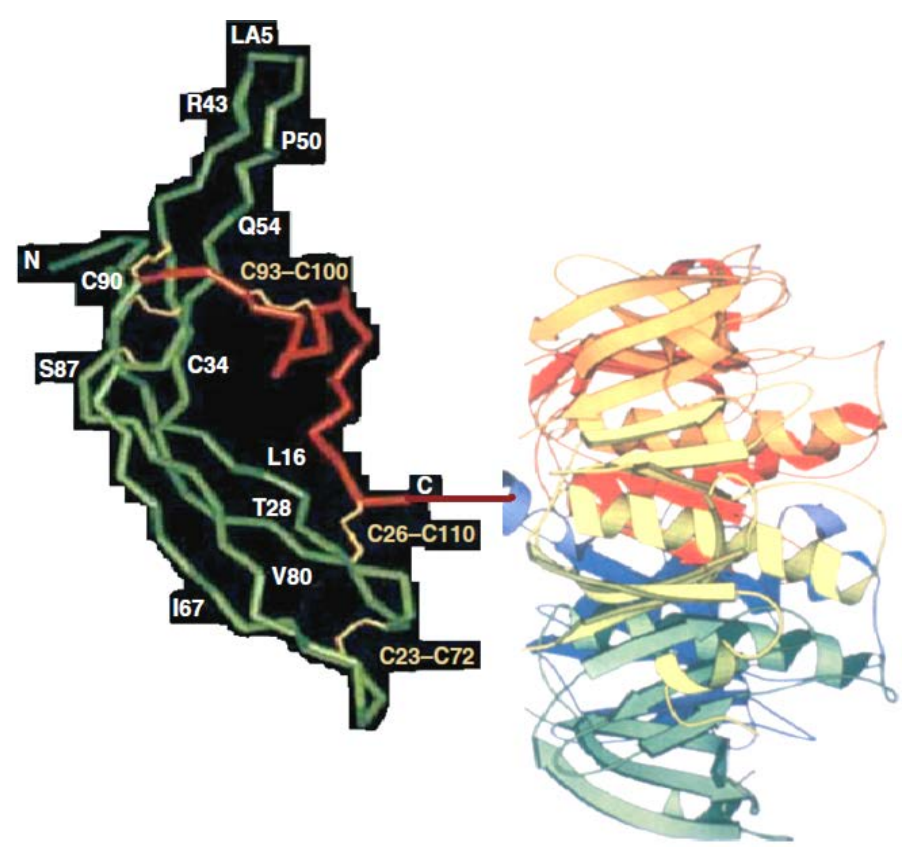

Figure 7. Conceptualized structure of hCG $\beta$-LTB vaccine. The carrier B chain of heat labile enterotoxin of $E$. coli (LTB) is fused at c-terminal glutamine of hCG $\beta$.

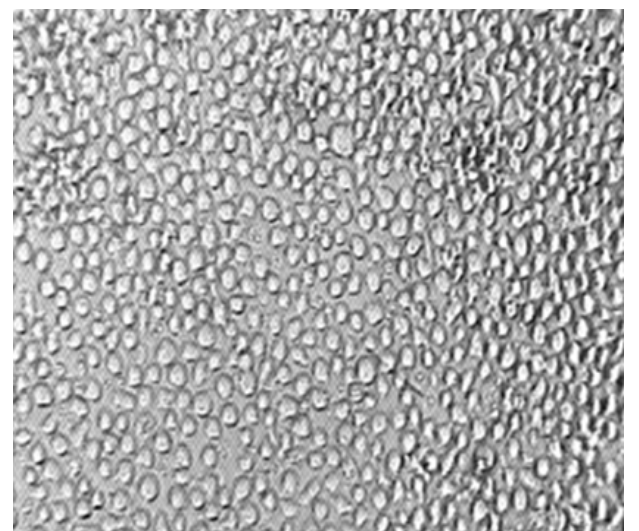

Control: MOLT-4 + Medium (20X)

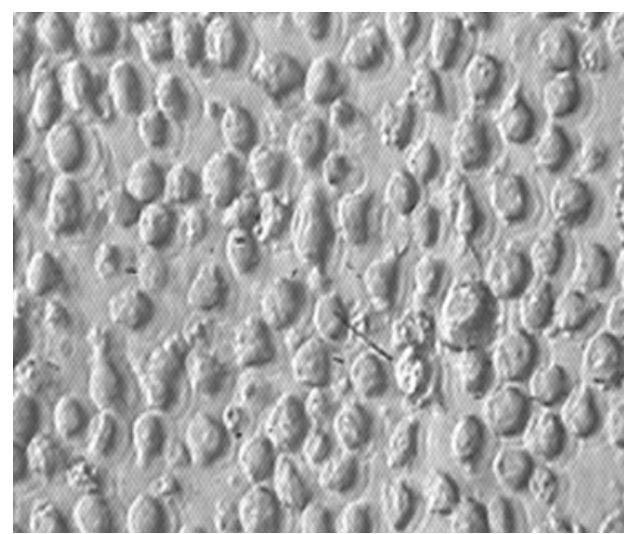

Control: MOLT-4 + Medium (40X)

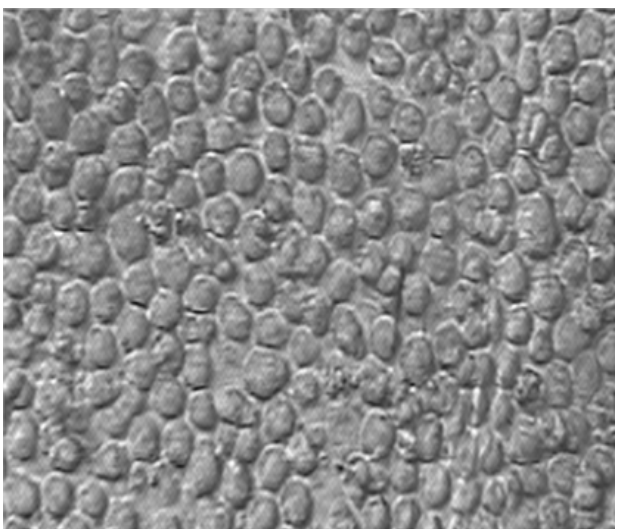

MOLT-4 + $50 \mu \mathrm{g}$ cPiPP antibody alone (40X)

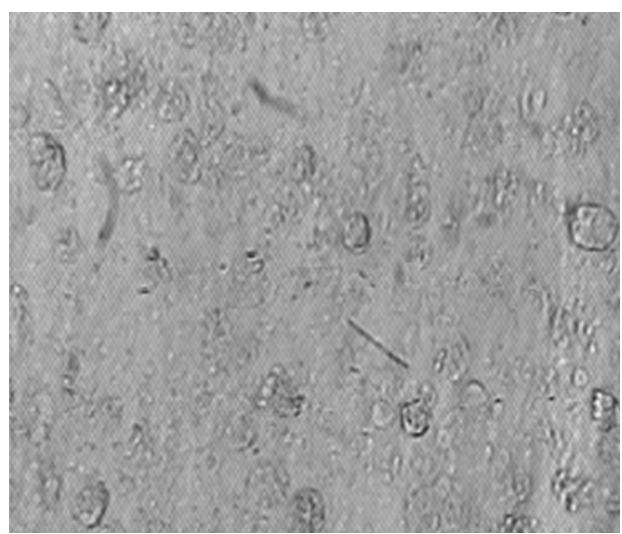

MOLT-4 + $50 \mu \mathrm{g}$ Curc-cPiPP conjugate (40X)

Figure 8. Photomicrograph of MOLT-4 cells after incubation with cPiPP alone and cPiPP-curcumin conjugate. Cells incubated in culture medium are used as control [26] [31]. 


\section{Magic Bullets}

It is not inconceivable that anti-hCG antibodies alone, may fail to kill a cancer cell expressing hCG alone or in presence of complement. MOLT-4, T-lymphoblastic leukemia cells, are an example [30]. These are positive for hCG but PiPP fails to kill these cells in culture with or without complement.

An alternate strategy was adopted. We linked curcumin, a highly safe compound purified from curcumin longa. Curcumin has anti-inflammatory and anti-cancerous properties. By linking it to PiPP, it could reach the cancer cells expressing hCG by virtue of the ability of the antibody to recognize and bind with hCG expressed by these cells and thereafter deliver curcumin to these cells. The conjugate caused nearly 100\% killing of cells [26] [31]. Almost all cancer cells were killed (Figure 8).

Thus antibody-curcumin conjugates can act as "Magic Bullets” reaching selectively the cancer cells expressing hCG and thereafter killing these via curcumin. Incidentally this approach will be highly economical. It can save the amount of antibody which needs to be given passively for therapeutic purposes.

\section{Acknowledgements}

The work recapitulated in this Review received research grants from the Indian Council of Medical Research, Department of Biotechnology, and Department of Science and Technology, Government of India.

\section{References}

[1] Talwar, G.P., Chaudhuri, M.K. and Jayshankar, R. (1992) Inventors. Antigenic Derivative of GnRH. UK Patent, 2228262.

[2] Talwar, G.P., Diwan, M., Dawar, H., Frick, J., Sharma, S.K. and Wadhwa, S.N. (1998) Counter GnRH Vaccine. In: Rajalakshmi, M. and Griffin, P.D., Eds., Male Contraception Present and Future. New Age International, New Delhi, 309-318.

[3] Talwar, G.P., Gupta, R., Gupta, S.K., Malhotra, R., Khanna, R., et al. (2001) A Monoclonal Antibody Cytolytic to Androgen Independent DU145 and PC3 Human Prostatic Carcinoma Cells. Prostate, 46, 207-213. http://dx.doi.org/10.1002/1097-0045(20010215)46:3<207::AID-PROS1025>3.0.CO;2-W

[4] Talwar, G.P., Gupta Jagdish, C., Yogesh, K., et al. (2014) Immunological Approaches for Treatment of Advanced Stage Cancers Invariably Refractory to Drugs. Journal of Clinical \& Cellular Immunology, 5, 247.

[5] Fishel, S.B., Edwards, R.G. and Evans, C.J. (1984) Human Chorionic Gonadotropin Secreted by Preimplantation Embryos Cultured in Vitro. Science, 223, 816-818. http://dx.doi.org/10.1126/science.6546453

[6] Yokotani, T., Koizumi, T., Taniguchi, R., Nakagawa, T., Isobe, T., et al. (1997) Expression of Alpha and Beta Genes of Human Chorionic Gonadotropin in Lung Cancer. International Journal of Cancer, 71, 539-544. http://dx.doi.org/10.1002/(SICI)1097-0215(19970516)71:4<539::AID-IJC6>3.0.CO;2-V

[7] Iles, R.K., Persad, R., Trivedi, M., Sharma, K.B., Dickinson, A., et al. (1996) Urinary Concentration of Human Chorionic Gonadotrophin and Its Fragments as a Prognostic Marker in Bladder Cancer. British Journal of Urology, 77, 6169. http://dx.doi.org/10.1046/j.1464-410X.1996.82910.x

[8] Nishimura, R., Koizumi, T., Morisue, K., Yamanaka, N., Lalwani, R., et al. (1995) Expression and Secretion of the Beta Subunit of Human Chorionic Gonadotropin by Bladder Carcinoma in Vivo and in Vitro. Cancer Research, 55, 1479-1484.

[9] Syrigos, K.N., Fyssas, I., Konstandoulakis, M.M., Harrington, K.J., Papadopoulos, S., et al. (1998) Beta Human Chorionic Gonadotropin Concentrations in Serum of Patients with Pancreatic Adenocarcinoma. Gut, 42, 88-91. http://dx.doi.org/10.1136/gut.42.1.88

[10] Alfthan, H., Haglund, C., Roberts, P. and Stenman, U.H. (1992) Elevation of Free Beta Subunit of Human Choriogonadotropin and Core Beta Fragment of Human Choriogonadotropin in the Serum and Urine of Patients with Malignant Pancreatic and Biliary Disease. Cancer Research, 52, 4628-4633.

[11] Bièche, I., Lazar, V., Noguès, C., Poynard, T., Giovangrandi, Y., et al. (1998) Prognostic Value of Chorionic Gonadotropin Beta Gene Transcripts in Human Breast Carcinoma. Clinical Cancer Research, 4, 671-676.

[12] Crawford, R.A., Iles, R.K., Carter, P.G., Caldwell, C.J., Shepherd, J.H., et al. (1998) The Prognostic Significance of Beta Human Chorionic Gonadotrophin and Its Metabolites in Women with Cervical Carcinoma. Journal of Clinical Pathology, 51, 685-688. http://dx.doi.org/10.1136/jcp.51.9.685

[13] Grossmann, M., Hoermann, R., Gocze, P.M., Ott, M., Berger, P., et al. (1995) Measurement of Human Chorionic Gonadotropin-Related Immunoreactivity in Serum, Ascites and Tumour Cysts of Patients with Gynaecologic Malignancies. European Journal of Clinical Investigation, 25, 867-873. http://dx.doi.org/10.1111/j.1365-2362.1995.tb01697.x 
[14] Hedström, J., Grenman, R., Ramsay, H., Finne, P., Lundin, J., et al. (1999) Concentration of Free hCGbeta Subunit in Serum as a Prognostic Marker for Squamous-Cell Carcinoma of the Oral Cavity and Oropharynx. International Journal of Cancer, 84, 525-528. http://dx.doi.org/10.1002/(SICI)1097-0215(19991022)84:5<525::AID-IJC14>3.0.CO;2-Q

[15] Bhalang, K., Kafrawy, A.H. and Miles, D.A. (1999) Immunohistochemical Study of the Expression of Human Chorionic Gonadotropin-Beta in Oral Squamous Cell Carcinoma. Cancer, 85, 757-762. http://dx.doi.org/10.1002/(SICI)1097-0142(19990215)85:4<757::AID-CNCR1>3.0.CO;2-T

[16] Scholl, P.D., Jurco, S. and Austin, J.R. (1997) Ectopic Production of Beta-HCG by a Maxillary Squamous Cell Carcinoma. Head \& Neck, 19, 701-705. http://dx.doi.org/10.1002/(SICI)1097-0347(199712)19:8<701::AID-HED8>3.0.CO;2-9

[17] Sheaff, M.T., Martin, J.E., Badenoch, D.F. and Baithun, S.I. (1996) Beta hCG as a Prognostic Marker in Adenocarcinoma of the Prostate. Journal of Clinical Pathology, 49, 329-332. http://dx.doi.org/10.1136/jcp.49.4.329

[18] Jiang, Y., Zeng, F., Xiao, C. and Liu, J. (2003) Expression of Beta-Human Chorionic Gonadotropin Genes in Renal Cell Cancer and Benign Renal Disease Tissues. Journal of Huazhong University of Science and Technology [Medical Sciences], 23, 291-293. http://dx.doi.org/10.1007/BF02829518

[19] Lundin, M., Nordling, S., Carpelan-Holmstrom, M., Louhimo, J., Alfthan, H., et al. (2000) A Comparison of Serum and Tissue hCG Beta as Prognostic Markers in Colorectal Cancer. Anticancer Research, 20, 4949-4951.

[20] Rau, B., Below, C., Liebrich, W., von Schilling, C. and Schlag, P.M. (1995) Significance of Serum B-hCG as a Tumor Marker for Stomach Carcinoma. Langenbeck's Archives of Surgery, 380, 359-364.

[21] Louhimo, J., Nordling, S., Alfthan, H., von Boguslawski, K., Stenman, U.H. and Haglund, C. (2001) Specific Staining of Human Chorionic Gonadotropin Beta in Benign and Malignant Gastrointestinal Tissues with Monoclonal Antibodies. Histopathology, 38, 418-424. http://dx.doi.org/10.1046/j.1365-2559.2001.01106.x

[22] De Bruijn, H.W., ten Hoor, K.A., Krans, M. and van der Zee, A.G. (1997) Rising Serum Values of Beta-Subunit Human Chorionic Gonadotrophin (hCG) in Patients with Progressive Vulvar Carcinomas. British Journal of Cancer, 75, 1217-1218. http://dx.doi.org/10.1038/bjc.1997.208

[23] Carter, P.G., Iles, R.K., Neven, P., Ind, T.E., Shepherd, J.H. and Chard, T. (1995) Measurement of Urinary Beta Core Fragment of Human Chorionic Gonadotrophin in Women with Vulvovaginal Malignancy and Its Prognostic Significance. British Journal of Cancer, 71, 350-353. http://dx.doi.org/10.1038/bjc.1995.70

[24] Hotakainen, K., Ljungberg, B., Paju, A., Rasmuson, T., Alfthan, H. and Stenman, U.-H. (2002) The Free Beta-Subunit of Human Chorionic Gonadotropin as a Prognostic Factor in Renal Cell Carcinoma. British Journal of Cancer, 86, 185-189. http://dx.doi.org/10.1038/sj.bjc.6600050

[25] Gupta, S.K., Ramakrishnan, S. and Talwar, G.P. (1982) Properties and Characteristics of an Anti-hCG Monoclonal Antibody. Journal of Biosciences, 4, 105-114. http://dx.doi.org/10.1007/BF02702586

[26] Talwar, G.P., Rulli, S.B., Vyas, H.K., et al. (2014) Making of a Unique Birth Control Vaccine against hCG with Additional Potential of Therapy of Advanced Stage Cancers and Prevention of Obesity and Insulin Resistance. Journal of Cell Science \& Therapy, 5, 1000159.

[27] Talwar, G.P., Puruswani, S. and Vyas, H.K. (2010) Immunological Approaches against Human Chorionic Gonadotropin for Control of Fertility and Advanced Stage Cancers Expressing Ectopically hCG. In: Kumar, A., Rao, C.V. and Chaturvedi, P.K., Eds., Gonadal and Nongonadal Action of Gonadotropins, Narosa Publishing House, New Delhi, 183-196.

[28] Purswani, S. and Talwar, G.P. (2011) Development of a Highly Immunogenic Recombinant Candidate Vaccine against Human Chorionic Gonadotropin. Vaccine, 29, 2341-2348. http://dx.doi.org/10.1016/j.vaccine.2010.11.069

[29] Purswani, S., Talwar, G.P., Vohra, R., et al. (2011) Mycobacterium indicus pranii Is a Potent Immunomodulator for a Recombinant Vaccine against Human Chorionic Gonadotropin. Journal of Reproductive Immunology, 91, 24-30. http://dx.doi.org/10.1016/j.jri.2011.06.099

[30] Kabeer, R.S., Pal, R. and Talwar, G.P. (2005) Human Acute Lymphoblastic Leukemia Cells Make Human Pregnancy Hormone hCG and Expose It on the Membrane: A Case for Using Recombinant Antibody against hCG for Selective Delivery of Drugs and/or Radiations. Current Science, 89, 1571-1576.

[31] Vyas, H.K., Pal, R., Vishwakarma, R., Lohiya, N.K. and Talwar, G.P. (2009) Selective Killing of Leukemia and Lymphoma Cells Expressing Ectopically hCG $\beta$ by a Conjugate of Curcumin with an Antibody against hCG $\beta$ Subunit. Oncology, 76, 101-111. http://dx.doi.org/10.1159/000188665 